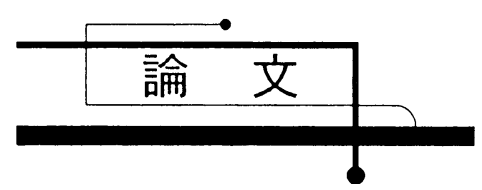

\title{
オゾンマイクロバブルを用いた高機能洗浄技術*
}

\section{High Performance Removal Technology using Ozone Microbubble}

\author{
新 井香 裕 ${ }^{*}$ \\ ARAI Yoshihiro
}

\author{
阿 部豊** \\ ABE Yutaka
}

\author{
金子 暁 子** \\ KANEKO Akiko
}

\author{
池昌 俊*** \\ IKE Masatoshi
}

\begin{abstract}
The removal technology of single-wafer processing using ozone is proposed on photoresist removal in the semiconductor manufacturing. Ozone is friendly for the environment and no harm to the product. Before now, the authors indicated that disk-shaped nozzle forms a vortex structure between the disks which is considered to cause the reduction of photoresist removal rate. This study proposes a disk-shaped convex nozzle to suppress the vortex. In order to investigate the effects of the presence or absence of the convex, the removal experiments were conducted. As a result, disk-shaped convex nozzle had the higher removal ability than disk-shaped nozzle in the convex part.

Next, as a new removal method, we suggest the ozone microbubble with a Venturi tube. To investigate the performance of the photoresist removal with it, first, the generation of ozone microbubbles is observed in the Venturi tube via a high speed video camera. Next, to clarify the effect of the superficial liquid and gas velocities, the ozone microbubble, and presence or absence of convex, ozone water concentration measurement and photoresist removal experiments were conducted. As a result, the ozone water concentration increased with increasing superficial velocity and the remaining photoresist thickness reduced. Also, ozone microbubble had the higher removal ability than ozone water single-phase. Compared presence and absence of convex, convex influenced photoresist removal efficiently. In addition, compared with the existing study, it is suggested that the superficial liquid and gas velocities and ozone water concentration affect the photoresist removal rate.
\end{abstract}

Keywords: Photoresist removal, Rotating disk, Convex, Ozone microbubble, Venturi tube

\section{1. 緒 言}

半導体製造過程のフォトレジスト除去では、従 来、熱濃硫酸などの薬液が用いられており、環境 への負荷や残留硫酸基の品質への悪影響が問題 となっている。対策として、環境に優しく、残留 硫酸基が発生しない、オゾン水を用いた洗浄方法 が提案されている。オゾンを用いた洗浄手法とし ては、オゾン水単相で洗浄するものとオゾンマイ クロバブルにより洗浄するものが提案されてい る。オゾンマイクロバブルとは、オゾンを含む直 径 $1 \mathrm{~mm}$ 以下の微細気泡を指している。オゾンマ イクロバブルによるレジスト洗浄に関して、
Takahashi らは、加圧溶解式のオゾンマイクロバ ブルを用いることで、オゾン水濃度が上昇し、洗 浄速度が向上することを示した[1,2]。しかし、そ の洗浄効率は熱濃硫酸の場合と比較して劣るた め、幅広く実用化されるには至っていない。

そこで、著者らはこれまでに、高効率なオゾン 洗浄手法として、Fig. 1(a)のような円盤型ノズル を用いてオゾン水を注流する枚葉式スピン洗浄 を提案している。しかしながら、円盤型ノズルを 用いると円盤終端部においてレジスト洗浄効率 低下の一因として考えられる渦構造の形成が実 験的に確認された[3-7]。

\footnotetext{
* 2016.4.24 受付

** 筑波大学大学院システム情報工学研究科構造エネルギー工学専攻 テ305-8573 茨城県つくば市天王台 1-1-1 TEL: (029)853-5226 FAX: (029)853-5226 E-mail: abe@kz.tsukuba.ac.jp

*** 合同会社アプテックス
} 


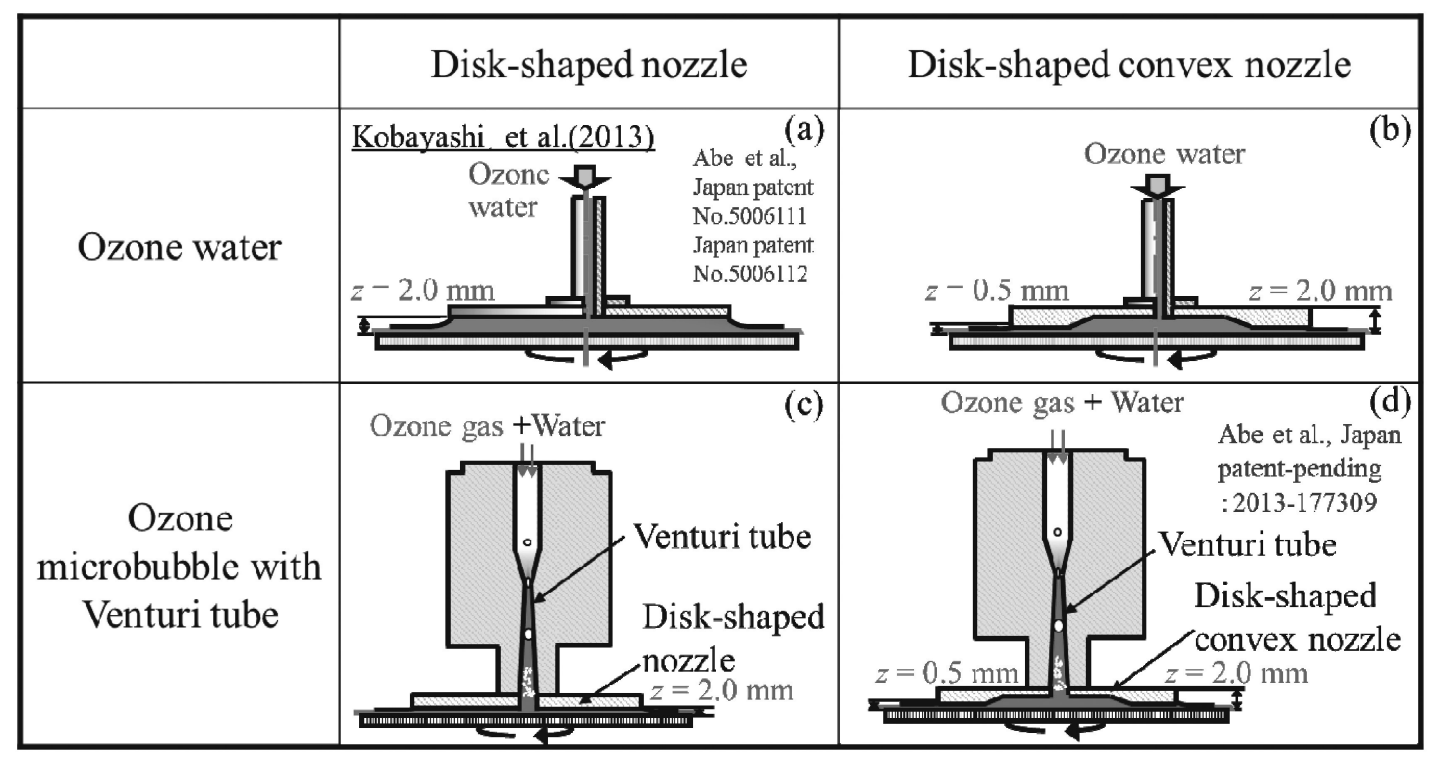

Fig. 1 Detail of nozzle shape.

そこで本研究では、渦構造を抑制し、レジスト 洗浄効率を向上させるために、Fig. 1(b)のように 円盤終端部に段差を設けた円盤段差付きノズル を提案する。また、更なる洗浄効率向上のための 手法として、ベンチュリ管を用いてオゾンマイク ロバブルを生成し、オゾンの気液二相流により洗 浄を行ら手法を提案する[8-11]。その手法として、 Fig. 1(c)と (d)に示すように、ベンチュリ管式円盤 型ノズルと段差を設けたベンチュリ管式円盤段 差付きノズルをあげる。ベンチュリ管によるレジ ス卜洗浄は高い洗浄効果が期待されるものの、ベ ンチュリ管式オゾンマイクロバブルによるレジ ス卜洗浄性能について全く調へられれいないの が現状である。

そこで本研究は、オゾン水単相における段差の 有無とベンチュリ管式オゾンマイクロバブルの 洗浄効果の解明を目的とする。オゾン水単相にお けるレジスト洗浄実験、ベンチュリ管内流動の可 視化、気泡径計測、オゾン水濃度計測、液相およ び気相見かけ速度・洗浄時間・オゾンマイクロバ ブルの有無・段差の有無を変更したレジスト洗浄 実験、オゾン水単相や既存研究との比較を通して 本洗浄手法の有用性を調べる。

\section{2. オゾンを用いた実験装置}

\section{1 オゾン水単相における実験装置}

実験に用いたノズルについて、Fig. 1(a)はノズ ル射出部に直径 $125 \mathrm{~mm}$ の円盤を取り付けた従来 の円盤型ノズルである。Fig. 1(b)は円盤型ノズル において半径位置 $25.7 \mathrm{~mm}$ から $35.7 \mathrm{~mm}$ までの間 に回転円盤との間隔 $z$ が $2.0 \mathrm{~mm}$ から $0.5 \mathrm{~mm}$ とな るように段差を設けた円盤段差付きノズルであ る。下部回転円盤は直径 $250 \mathrm{~mm}$ であり、時計回 りに回転する。

レジスト洗浄実験において使用した実験装置 の概略図をFig. 2 に示す。実験装置全体は全てメ タルフリーで構成した。生成したオゾン水 $10 \mathrm{~L}$ をタンクにいれ、各ノズルを用いて 400 s、レジ スト洗浄を行った。使用したオゾン水はドレイン から排出される。使用したシリコンウェハは、 Philtech 社製の直径約 $200 \mathrm{~mm} の 8$ inch ウェハで ある。シリコンウェハ表面には全面に渡って膜厚 が $1000 \mathrm{~nm}$ で均一となるようにi 線ポジ型フォト レジストが塗布されている。レジスト洗浄後の残 存レジス卜膜厚を膜厚測定器（Avantes 社製 AvaSpec-2048-USB2）を用いて測定した。実験条 件は、回転速度 $\Omega=300 \mathrm{rpm}$ 、水流量 $Q=1.0 \mathrm{~L} / \mathrm{min}$ 、 円盤間隔 $z=2.0 \mathrm{~mm}$ とした。実験に用いたオゾン 水濃度は KI 法により測定し、円盤型ノズルの時 は $C_{\mathrm{L}}=22.1 \mathrm{mg} / \mathrm{L}$ 、円盤段差付きノズルでは $C_{\mathrm{L}}=$ $24.9 \mathrm{mg} / \mathrm{L}$ である。 


\section{2 オゾンマイクロバブルにおける実験装置}

ここではベンチュリ管を用いてオゾンマイク ロバブルを生成し、レジスト洗浄を行う。まず、 レジスト洗浄実験を行う前に、ベンチュリ管によ りオゾンマイクロバブルが生成される様子を調 ベる。

オゾンマイクロバブルに関する実験で用いた 実験装置の概略図をFig. 3 に示す。ベンチュリ管 を用いた実験装置においては、液相供給部、気相 供給部、洗浄部の 3 つで構成されている。液相供 給部は、タンク（60 L ） とポンプ、流量調整のた めのインバータ、渦流量式液相流量計 (Keyence 社製FD-P20)で構成されている。気相供給部は、 酸素ボンベ（純度 99.99\%） とバルブ、スピード コントローラ、渦流量式流量計（Keyence 社製 FD-A1、FD-A10)、オゾンガス発生装置（アプテ ックス社製 O3G-C180U）から成る。洗浄部は、 気相混合部、ベンチュリ管で構成されている。べ ンチュリ管内の流動を調べるため、ハイスピード ビデオカメラにより撮影した。撮影条件は、撮影

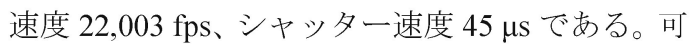
視化の際はベンチュリ管出口を大気開放した状 態で、メタルハライドランプで後ろからベンチュ リ管に光を当てながらバックライト法にて行っ た。オゾン水濃度計測時には、ベンチュリ管出口 にオゾン水濃度計測器 (Applics 社製 OD-UND) を接続し、紫外線吸収法により濃度計測を行った。 ここでは $\mathrm{i}$ 線フォトレジストを塗布したシリコ ンウェハに対してオゾンマイクロバブルを噴射 し、洗浄実験を行う。高価なシリコンウェ八を経 済的に利用するため、ウェハの一部を用いる場合 と 8 inch ウェ八全体を用いる場合について実験 を実施した。まず、洗浄性能を調べるために噴流 直下のみ評価する場合の実験装置を Fig. 3 に示 す。この場合には、一辺 $30 \mathrm{~mm}$ に切り出したレ ジストをアクリル製のフォルダーに入れ、ベンチ ユリ管の噴流直下に垂直に設置する。管出口とレ ジストの間隔は $25 \mathrm{~mm}$ である。本実験装置では、 円盤型ノズル等は使用せず、回転もしない条件と なる。

次に、レジスト全体を評価する場合の実験装置 をFig. 4 に示す。本実験装置では、ベンチュリ管 に円盤型ノズルや円盤段差付きノズルを使用し、 流速や段差の有無によってレジスト洗浄効果に 与える影響を調べる。洗浄実験時は、円盤間にお

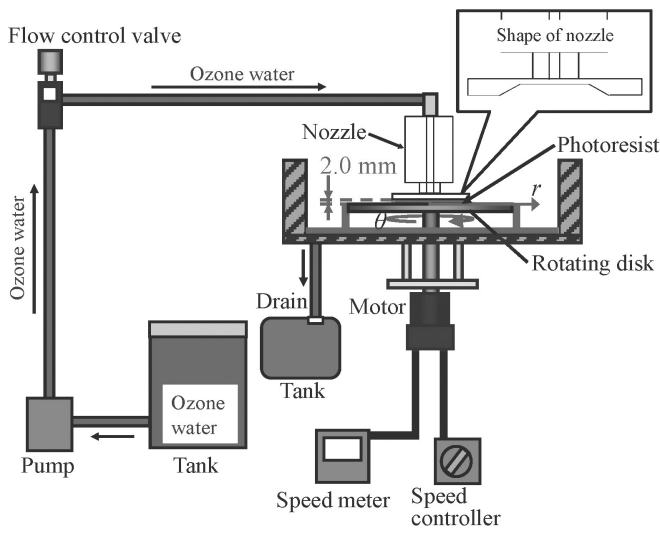

Fig. 2 Schematic of the experimental apparatus to remove with ozone water single-phase.

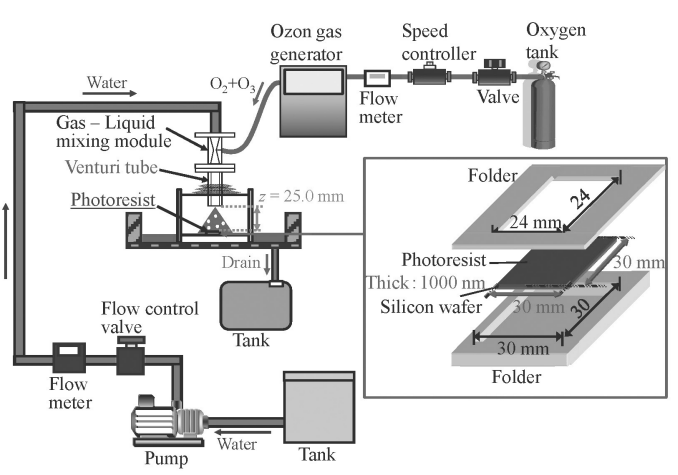

Fig. 3 Schematic of the experimental apparatus to remove with the Venturi tube.

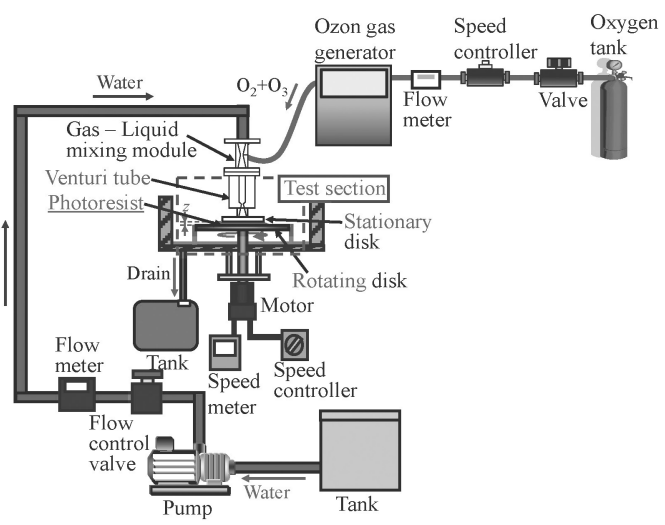

Fig. 4 Schematic of the experimental apparatus to remove with rotating. 
いてオゾン水の液膜は形成されず、気相と液相が 混ざった流動様式となる。本実験では、水道水を 用いた。いずれの実験においてもタンク内の水温 は20 25ㄷの範囲で一定であることを確認してい る。

使用したベンチュリ管は、Fig. 5 に示すような 透明なアクリル製であり、Fig. 5(a)のベンチュリ 管は、断面が矩形、入口部の幅 $14 \mathrm{~mm}$ 、奥行き 5 $\mathrm{mm}$ 、喉部の幅 $4 \mathrm{~mm}$ 、出口部の幅 $8.2 \mathrm{~mm}$ 、開き 角 $6^{\circ}$ である。また、Fig. 5(b)のベンチュリ管は、 断面が円形、喉部の幅 $2 \mathrm{~mm}$ 、出口部の幅 $9 \mathrm{~mm}$ 、 開き角 $6^{\circ}$ である。それぞれのベンチュリ管の 先端には、半径 $62.5 \mathrm{~mm}$ の円盤ノズル又は円盤段 差付きノズルを取り付ける。比較対象であるオゾ ン水単相の実験では、直径 $9 \mathrm{~mm}$ のストレート管 を使用し、オン゙ン水の生成方法としてオゾン溶解 膜モジュール（住友電工ファインポリマー社製 PM-201FPG）を用いた。

ベンチュリ管における実験条件を Fig. 6 に示 す。ベンチュリ管入口圧力を計測した結果より入 り口圧力を $150 \mathrm{kPa}$ と仮定し、このときに喉部で 気液二相流の流速が音速に達する条件を図中に 実線で示す。この線より液相見かけ流速 $j$ Lin が大 きい場合には喉部以下の流れが超音速流れにな り、急激な圧力変化とそれに伴う気泡崩壊が発生 すると考えられる。この実線よりも液相見かけ流 速 $j_{\text {Lin }}$ が小さい場合には、流れが超音速にならず、 急激な圧力変化は発生しないと考えられる。

Uesawa らや Kaneko ら、Tamura らにより、のど 部で流速が音速に達するか否かで拡大部での流 動が大きく変化し、洗浄に影響を与える[8-10]こ とが示唆されていることから、本条件では、超音 速を超える場合と超えない場合の両方を比較す るため、図中の赤丸で示寸条件で実験を行う。

\section{3. オゾン水単相におけるレジスト洗浄実験}

Fig. 2 に示寸実験装置を用いてレジスト除去を 行った後のレジスト表面の様子をPhoto 1 に示す。 Photo 1 の左側は円盤型ノズルの結果を、Photo 1 の右側は円盤段差付きノズルによる結果を示す。 シリコンウェハ表面はレジストの除去量により 色が変化する。Photo 1 のシリコンウェハは共に ノズル流入部では色の変化が著しく、端に向かう につれ色の変化は少ない。また、Photo 1 の右側 は、Photo 1 の左側と比較すると、段差部分にお

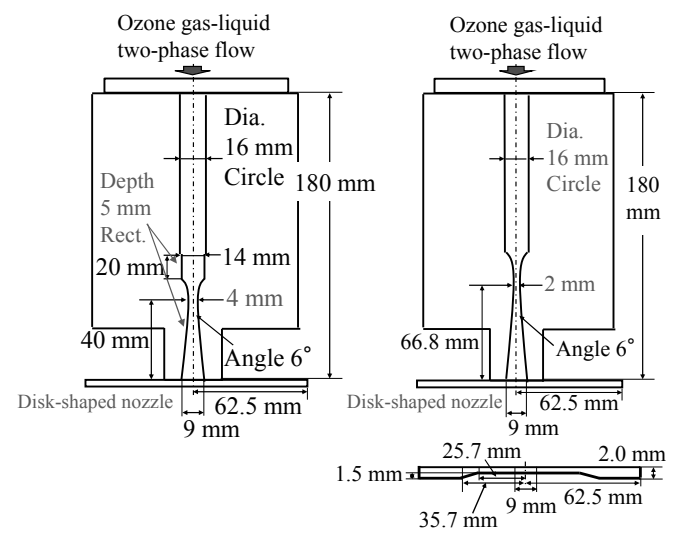

(a) Disk-shaped nozzle (b) Disk-shaped convex nozzle

Fig. 5 Detail of disk-shaped and disk-shaped convex nozzle with two Venturi tubes.

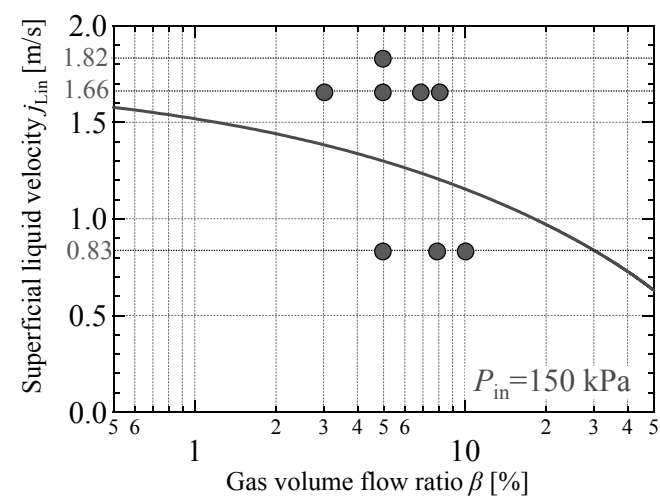

Fig. 6 Experimental conditions.

いて色の違いがみられる。これはレジストの除去 量が変化していることが原因である。

そこで、シリコンウェハ表面の残存レジスト膜 厚を膜厚測定器によって測定した結果を Fig. 7 に示す。いずれも洗浄時間 $T=400 \mathrm{~s}$ とした。円 盤型ノズルと円艋段差付きノズルでは、レジスト 全面に渡って残存レジスト膜厚に違いがみられ た。これは、レジスト洗浄を行う際のオゾン水濃 度が、円盤型ノズルでは $22.1 \mathrm{mg} / \mathrm{L}$ であり、円盤 段差付きノズルでは $24.9 \mathrm{mg} / \mathrm{L}$ と違いがあったこ とが影響しているものと考えられる。両ノズル共 に、ノズル流入部においてレジストが最もよく除 去されているのがわかる。残存レジスト膜厚は円 盤終端部に向からにつれて少なくなり、円盤全体 で残存レジスト膜厚が不均一であることがわか 
る。円盤段差付きノズルでは、円盤型ノズルと比 較して、段差部分においてレジストがより除去さ れているのがわかる。レジストは段差が始まる半 径位置からよく除去され始めるのではなく、段差 が終わる半径位置付近からより除去され始め、円 盤端に向からにつれて残存レジスト膜厚が円盤 型ノズルと同様の值に近づいている。

\section{4. オゾンマイクロバブルにおける実験結果}

\section{1 管内・円盤間流動とレジスト洗浄性能}

オゾンマイクロバブルにおけるレジスト洗浄 について、液相・気相見かけ速度 $j_{\text {Lin }} 、 j_{\text {Gin }}$ 変え た時のベンチュリ管内における気泡挙動の変化 を観察した結果をFig. 8 に示す。Fig. 8(A)は、 $j_{\text {Lin }}$ $=0.83 \mathrm{~m} / \mathrm{s} 、 j_{\text {Gin }}=0.04 \mathrm{~m} / \mathrm{s}$ における気泡崩壊挙動 であり、丸印で示すように、気泡は喉部に流入後、 引きちぎられるように分裂する様子が観察され た。一方、Fig. 8(B)の $j_{\text {Lin }}=1.66 \mathrm{~m} / \mathrm{s} 、 j_{\text {Gin }}=0.09 \mathrm{~m} / \mathrm{s}$ においては、流入した気泡がベンチュリ管喉部を 通過後に膨張し、急激に収縮・崩壊し、微細気泡 が生成されている様子が見られた。これより、流 速を変えることでベンチュリ管内の流動が大き く変わることがわかる。

次に、高速度ビデオカメラにより得られた画像 から、画像処理によりベンチュリ管出入口におけ る気泡径分布を算出した結果をFig. 9 に示す。Fig. 9(A)から、 $j_{\text {Lin }}=0.83 \mathrm{~m} / \mathrm{s} 、 1.66 \mathrm{~m} / \mathrm{s}$ のどちらにお いても、ベンチュリ管入口に比べ出口では気泡径 が小さくなることがわかる。また、出口における 気泡径の最頻值は、 $j_{\text {Lin }}=0.83 \mathrm{~m} / \mathrm{s} 、 1.66 \mathrm{~m} / \mathrm{s}$ にお いてそれぞれ直径 $150 \mu \mathrm{m} 、 100 \mu \mathrm{m}$ となり、 $j_{\mathrm{Lin}}=$ $1.66 \mathrm{~m} / \mathrm{s}$ の方が小さな気泡径であることが確認さ れた。これは、見かけ速度を増加させることで Fig. 8 で見られた気泡崩壊挙動の違いを引き起こ し、気泡径分布の違いに影響が出たと考えられる。 ベンチュリ管出口におけるオゾン水濃度を調 べた結果を Table 1 に示す。 $j_{\text {Lin }}=1.66 \mathrm{~m} / \mathrm{s}$ では 8 $\mathrm{mg} / \mathrm{L}$ と、 $j_{\mathrm{Lin}}=0.83 \mathrm{~m} / \mathrm{s}$ の時の $6 \mathrm{mg} / \mathrm{L}$ より高い濃 度となっていることがわかる。このことから、べ ンチュリ管内挙動およびオゾンマイクロバブル の気泡径がオゾン水濃度に影響を与えているこ とが考えられる。

ベンチュリ管式オゾンマイクロバブルにおけ る噴流直下のレジスト洗浄性能を調べるために、 Fig. 3 に示す実験装置を用いて流速を変更しレジ

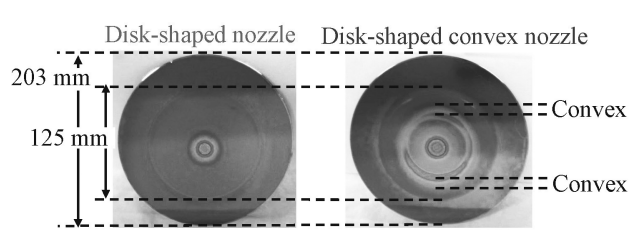

Photo 1 Surfaces of photoresist after removal.

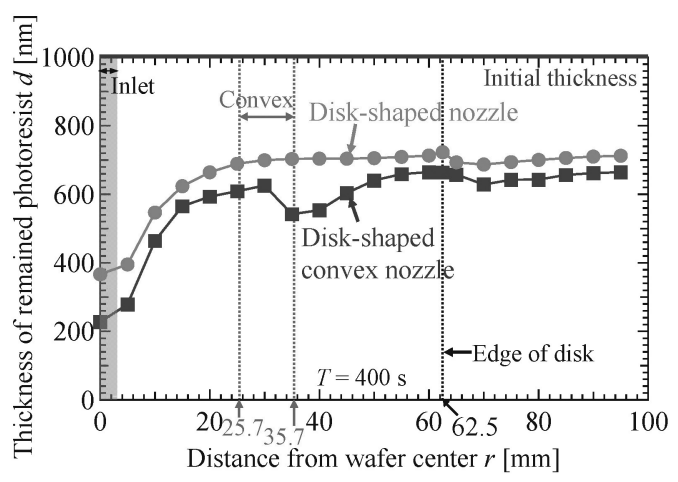

Fig. 7 Thickness of remained photoresist in ozone water single-phase.

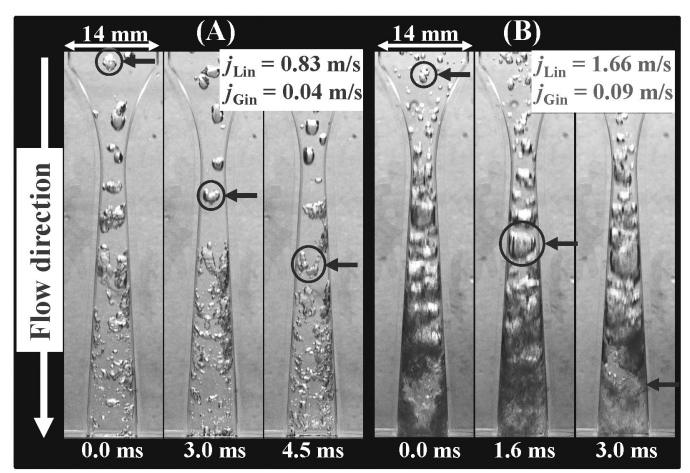

Fig. 8 Snapshots of bubbles in the Venturi tube.

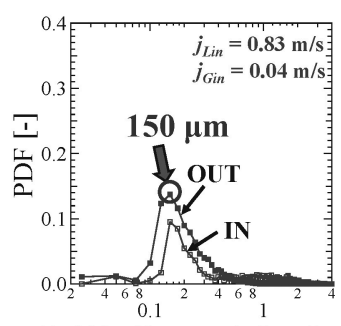

Bubble diameter $D[\mathrm{~mm}]$

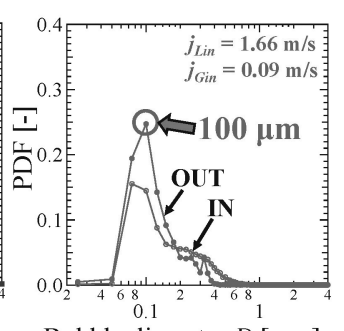

Bubble diameter $D[\mathrm{~mm}]$
(A) $j_{\text {Lin }}=0.83 \mathrm{~m} / \mathrm{s}$.

(B) $j_{\text {Lin }}=1.66 \mathrm{~m} / \mathrm{s}$.

Fig. 9 Bubble diameter. 
スト洗浄実験を行った。洗浄後のレジスト表面を Fig. 10 に示す。表面の色が流速および洗浄時間 に伴い異なることがわかる。Fig. 10(A)(2)と(B)(4) を比較すると、(2)においては、まだレジストが存 在している様子に対して、(4)では銀色となり噴流 直下位置のレジストがすべて除去されている様 子が分かる。

次に、残存レジスト膜厚を定量評価するために 白色点線上(Fig. 102))に一直線に(1)〜(4)までを計 測した結果をFig. 11 に示す。どちらの流速にお いても、洗浄時間の増加と共に残存レジスト膜厚 が減少していることがわかる。また、 $j_{\text {Lin }}=1.66 \mathrm{~m} / \mathrm{s}$ では、 $j_{\text {Lin }}=0.83 \mathrm{~m} / \mathrm{s}$ に比べて、同じ洗浄時間にお いて残存レジスト膜厚が薄いことがわかった。 $j_{\text {Lin }}$ $=1.66 \mathrm{~m} / \mathrm{s}$ において、噴流直下ですべてのレジス トが除去されることが確認された。

次に、喉部幅 $4 \mathrm{~mm}$ のベンチュリ管式円盤型ノ ズルを用いてレジスト全体の洗浄評価を行った 結果を Fig. 12 に示す。実験条件は、入口液相見 かけ流速 $0.83 、 1.66 \mathrm{~m} / \mathrm{s}$ 、気相体積流量比 $5 \%$ 、 回転速度 $300 \mathrm{rpm}$ 、冈盤間隔 $2 \mathrm{~mm}$ 、洗浄時間 $T=$ $8 \mathrm{~min}$ とした。赤線は流速 $1.66 \mathrm{~m} / \mathrm{s}$ 、青線は流速 $0.83 \mathrm{~m} / \mathrm{s}$ の時の結果であり、流速が大きい方が、 残存レジスト膜厚が少ないことがわかる。これは、 Fig. 11 に示した結果と同様であることから、レ ジスト洗浄に与える流速の影響が大きいことを 示唆する。

次に、オゾンマイクロバブルの有用性を調べる ために、オゾン水単相との比較を行った結果を

Fig. 13 に示す。これは、円盤型ノズルにより、 液相流量 $Q_{\mathrm{L}}=20 \mathrm{~L} / \mathrm{min}$ 、気相流量 $Q_{\mathrm{G}}=1.05 \mathrm{~L} / \mathrm{min}$ 、 回転速度 $\Omega=300 \mathrm{rpm}$ 、円盤間隔 $z=2.0 \mathrm{~mm}$ 、洗浄 時間 $T=5 \mathrm{~min}$ とした時の結果である。まず、生 成されるオゾン水濃度は、オゾン水単相において $4 \mathrm{mg} / \mathrm{L}$ であるのに刘して、オゾンマイクロバブル では $8 \mathrm{mg} / \mathrm{L}$ であることから、本洗浄手法のオゾ ン水生成效率が高いことがわかる。洗浄結果を見 ると、全体としてオゾンマイクロバブルにおいて 残存レジスト膜厚が少ないことがわかる。また、 残存レジス卜膜厚の傾向を見ると、オゾン水単相 ではノズル中心と円盤端で膜厚にばらつきがあ るのに対し、オゾンマイクロバブルではばらつき が少なく、均一に洗浄されている様子が見られる。 これは、本洗浄手法の特徵であると考えられる。 次に、Fig. 5 に示寸喉部幅 $2 \mathrm{~mm}$ のベンチュリ
Table 1 Ozone water concentration.

\begin{tabular}{|l|c|c|}
\hline $\begin{array}{l}\text { Ozone water concentration } \\
\text { outlet of the venturi tube } C_{\text {Lout }}[\mathrm{mg} / \mathrm{L}]\end{array}$ & $\mathbf{6}$ & $\mathbf{8}$ \\
\hline Superficial liquid velocity $j_{\text {Lin }}[\mathrm{m} / \mathrm{s}]$ & 0.83 & 1.66 \\
\hline Superficial gas velocity $j_{\text {Gin }}[\mathrm{m} / \mathrm{s}]$ & 0.04 & 0.09 \\
\hline Gas volume flow ratio $\beta[\%]$ & 5 & 5 \\
\hline
\end{tabular}

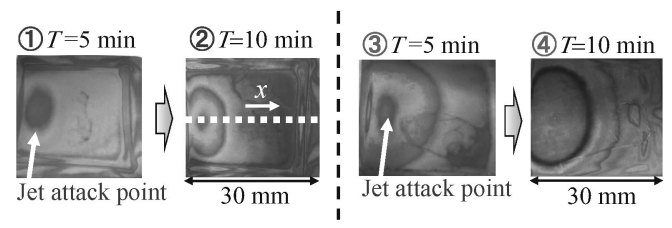
(A) $j_{\text {Lin }}=0.83 \mathrm{~m} / \mathrm{s}$.
(B) $j_{\text {Lin }}=1.66 \mathrm{~m} / \mathrm{s}$.

Fig. 10 Surfaces of photoresist after removal.

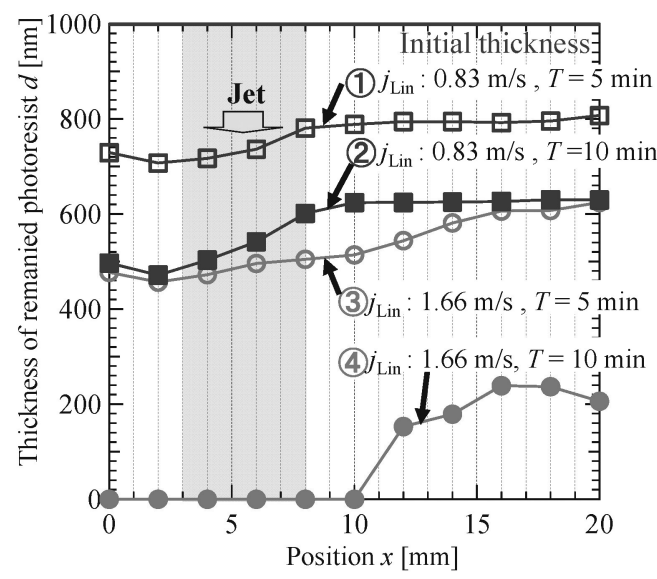

Fig. 11 Thickness of remained photoresist under the Venturi tube.

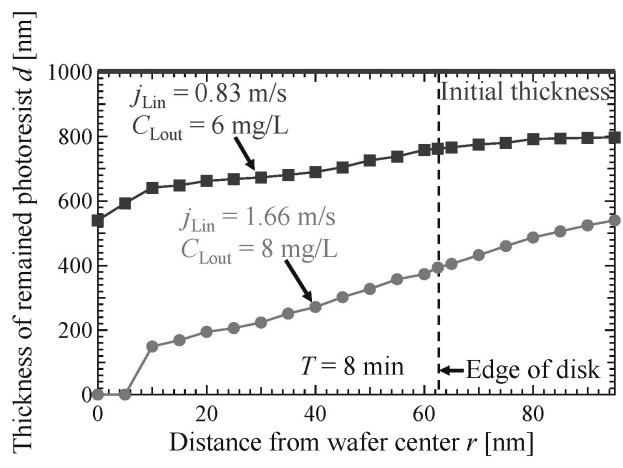

Fig. 12 Thickness of remained photoresist on a whole silicon wafer. 
管を用いて段差の有無によるレジスト洗浄実験 を行った結果を Fig. 14 に示す。実験条件は、液 相流速 $j_{\mathrm{Lin}}=0.249 \mathrm{~m} / \mathrm{s}$ 、気相流速 $j_{\text {Gin }}=0.013 \mathrm{~m} / \mathrm{s}$ 、 円盤間隔 $z=2.0 \mathrm{~mm}$ 、回転速度 $\Omega=300 \mathrm{rpm}$ 、洗浄 時間 $T=10 \mathrm{~min}$ とした。その結果、段差部分から 円盤端までの領域において円盤段差付きノズル の方が小さい残存レジスト膜厚となることがわ かった。これより、オゾンマイクロバブルにおい ても、円盤に段差を設けることでオゾン水単相と 同様に段差部分で高い洗浄効果を有することが 示された。

\section{2 既存研究との比較}

本研究によるレジスト洗浄実験で得られた洗 浄速度を整理し、既存の洗浄体系と比較する。比 較対象には産業総合技術研究所の Takahashi らの レジスト洗浄実験結果を引用した[1]。Takahashi らは加圧溶解式オゾンマイクロバブル生成法を 用いてレジスト洗浄実験を行っている。既存手法 である Takahashi らの洗浄結果と本研究における 実験結果を比較したものを Fig. 15 に示す。本洗 浄技術における洗浄速度は、最もレジスト洗浄速 度が大きい噴流直下位置における值を使用した。 オゾンマイクロバブルによる洗浄は 0.5 分間洗 浄した結果であり、オゾン水単相による洗浄は 5 分間洗浄した結果を示している。青色の四角のプ ロットは液相流速 $j_{\mathrm{Lin}}=0.83 \mathrm{~m} / \mathrm{s}$ において気相流 速を変えた時の結果を示しており、赤丸のプロッ 卜は、液相流速 $j_{\mathrm{Lin}}=1.82 \mathrm{~m} / \mathrm{s} 、 1.66 \mathrm{~m} / \mathrm{s}$ において 気相流速を変更させた時の結果、紫色の砂時計の 形のプロットはオゾン水単相において液相流速 $j_{\mathrm{Lin}}=5.24 \mathrm{~m} / \mathrm{s}$ とした時の結果を表している。まず、 オゾンマイクロバブルによる結果は、オゾン水単 相に比べて高い洗浄速度を有している。そして、 オゾンマイクロバブルにおける洗浄は、流速及び オゾン水濃度の増加に伴い、レジスト洗浄速度が 増加していることがわかる。また、既存手法であ る Takahashi らの結果と比較すると、液相流速 $j$ Lin $=0.83 \mathrm{~m} / \mathrm{s}$ においては、既存手法と同じまたは約 2 倍であるのに対し、液相流速 $j_{\mathrm{Lin}}=1.66 \mathrm{~m} / \mathrm{s}$ では、 既存手法に比べて約 2〜4 倍高い洗浄速度となる ことが分かった。以上のことから、本洗浄手法が 既存手法に比べて高い洗浄効果を有することが 示唆された。

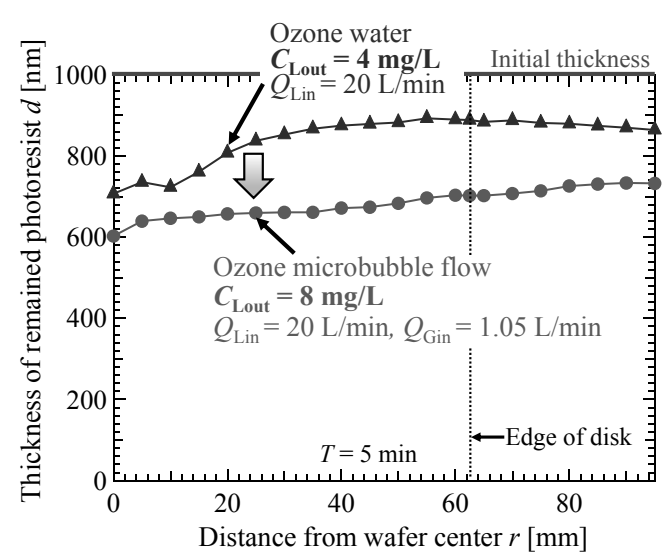

Fig. 13 Thickness of remained photoresist with ozone water and ozone microbubble flow.

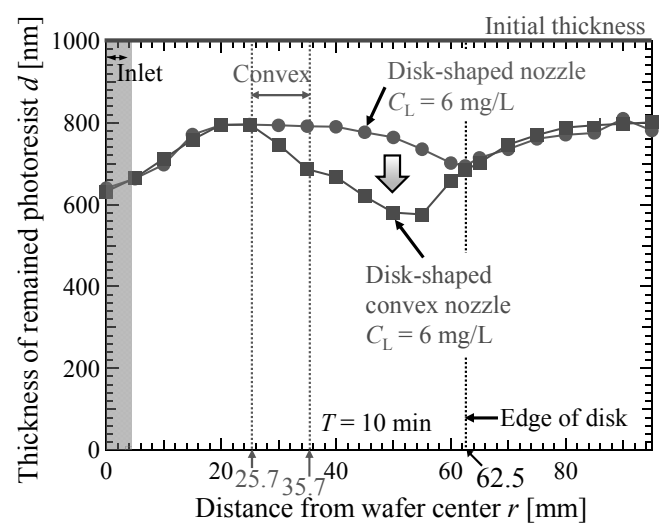

Fig. 14 Thickness of remained photoresist with disk-shaped and disk-shaped convex nozzle.

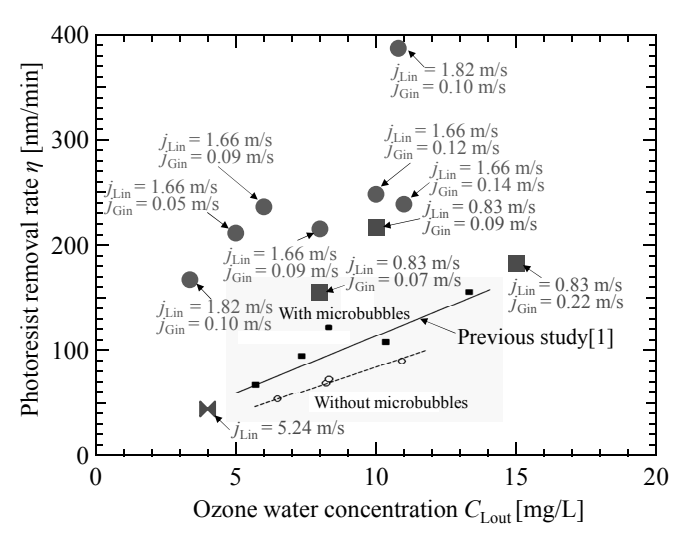

Fig. 15 Comparison with previous study[1]. 


\section{5. 結 言}

本研究では、オゾン水単相における段差の有無 とベンチュリ管式オゾンマイクロバブルの洗浄 効果の解明を目的として、以下の知見を得た。

・円盤型と円盤段差付きノズルでレジスト洗浄実 験を行い、段差部分において円盤段差付きノズル の方がレジストをより除去することが、オゾン水 単相とオゾンマイクロバブルの両方で示された。 ・流速を変えることで、ベンチュリ管内流動が変 化し、流速が大きい条件では、より微細なオゾン マイクロバブルが生成されることを確認した。 ・ベンチュリ管式オゾンマイクロバブル洗浄は、 オゾン水単相による洗浄に比べて、管出口のオゾ ン水濃度が大きく、高い洗浄効果を有することが 示された。

- 洗浄時間の増加や入口液相流速の増加に伴い、 残存レジスト膜厚が減少することが示された。

・ベンチュリ管式オゾンマイクロバブルによる洗 浄は、流速およびオゾン水濃度の影響を強く受け、 既存手法に比べて、約 2 4 倍高い洗浄速度を有 することがわかった。

\section{謝 辞}

本論文では、JSPS 科研費 $15 \mathrm{~K} 05781$ の助成を受 けた。ここに、感謝の意を表する。

\section{Nomenclature}

$\begin{array}{llr}d & : \text { thickness of remained photoresist } & {[\mathrm{nm}]} \\ j & : \text { superificial velocity } & {[\mathrm{m} / \mathrm{s}]} \\ r & : \text { radial position } & {[\mathrm{mm}]} \\ Q & : \text { Liquid rate } & {[\mathrm{L} / \mathrm{min}]} \\ D & : \text { bubble diameter } & {[\mathrm{mm}]} \\ C & : \text { ozone water concentration } & {[\mathrm{mg} / \mathrm{L}]} \\ T & : \text { time } & {[\mathrm{s}]} \\ z & : \text { distance between disks } & {[\mathrm{mm}]}\end{array}$

\section{Greek letters}

$$
\begin{array}{ll}
\beta & : \text { gas volume flow ratio } \\
\Omega & : \text { rotating speed } \\
\eta & : \text { photoresist removal rate }
\end{array}
$$

\section{Subscripts}

$\begin{array}{ll}G & : \text { gas phase (ozone) } \\ L & : \text { liquid phase (water) } \\ \text { in } & : \text { inlet } \\ \text { out } & : \text { outlet }\end{array}$

\section{参考文献}

[1] Takahashi, M., Ishikawa, H., Asano, T. and Horibe, H., Effect of Microbubbles on Ozonized Water for Photoresist Removal, J. Phys. Chem. C, Vol. 116, 12578-12583 (2012).

[2] Takahashi, M., Chiba .K and Li, P., Free-Radical Generation from Collapsing Microbubbles in the Absence of a Dynamic Stimulus, J. Phys. Chem. B, Vol. 111(6), 1343-1347 (2007).

[3] Soong, C.-Y., Wu, C.-C., Liu, T.-P. and Liu, T.-P., Flow Structure between Two Co-Axial Disks Rotating independently, Experimental Thermal and Fluid Science, Vol. 27, 295-311 (2003).

[4] Kobayashi, M. and Abe, Y., CFD Analysis of Flow Structure between Rotating Disks for Semiconductor Photoresist Stripping Using High Concentrated Ozone Water, Transactions of the Japan Society of Mechanical Engineers, Series B, Vol. 79(806), 1900-1914 (2013).

[5] Kobayashi, M. and Abe, Y., Study on the Flow Structure between Rotating Disks for Semiconductor Photoresist Stripping Using High Concentrated Ozone Water, Transactions of the Japan Society of Mechanical Engineers, Vol. 79(806), 1915-1926 (2013).

[6] Abe, Y., Fujimori, K. and Ike, M., Photoresist Removal System (in Japanese), Japanese Patent, No. 2008-311256 (2008).

[7] Abe, Y., Fujimori, K. and Ike, M., Photoresist Removal Method (in Japanese), Japanese Patent, No. 2008-311257 (2008).

[8] Uesawa, S., Kaneko, A., Nomura, Y. and Abe, Y., Fluctuation Void Fraction in the Microbubble Generator with a Venturi Tube, Proc. ASME/JSME/KSME Joint Fluids Eng. Conf., Paper No. AJK2011-10014 (2011).

[9] Kaneko, A., Nomura, Y., Takagi, S., Matsumoto, Y. and Abe, Y., Bubble Break-Up Phenomena in a Venturi Tube, Transactions of the Japan Society of Mechanical Engineers, Series B, Vol.78(786), 207-217 (2012).

[10] Tamura, N., Kaneko, A., Uesawa, S., Abe, Y. and Ike, M., Development of Non-chemical Micro-bubble Washing Technology Using a Venturi Tube, Japanese Journal of Multiphase Flow, Vol. 27(5), 577-584 (2014).

11] Abe, Y. and Ike, M., Removal System and Removal Method (in Japanese), Japan patent-pending, No. 2013-177309 (2013). 